\title{
Conforming or Confirming? The Task of Muslim Intelligentsia
}

\author{
Karim Douglas Crow*
}

Religious Traditions flourish over time in the forms their adherents re-live and reimagine them. By this creative historical process great religions have continually adapted themselves, successive generations reshaping and transforming received Tradition. And religion still holds the power to re-shape individuals and to transform the human existence we share in common. "To re-live or to re-imagine inherited religious traditions" - what does this mean in the age of pervasive globalisation? The great majority of religious adherents are convinced that their own doctrinal faith tradition has maintained its original integrity reaching them essentially unaltered with a pristine efficacy continuing to function as it did over centuries. For most religious persons Truth is ever one and the same, it does not change fashionably with the times but retains eternal validity with its original format. Our responsibility is to conform to this unchanging truth - not to realise its confirmation in one's direct experience.

How do Muslims understand the relevance of their timeless tradition for humanity now? We return to the question: What does it mean to re-live or reimagine inherited religious traditions? Do Islamic teachings and civilisational principles enjoin upon Muslims an effort at creative re-thinking and reappropriation? We saw that for many Muslim religious authorities: "Truth is finality and certainty...there is nothing to re-imagine." Muslims are expected to remain faithful to what is received as an unchanging universal Tradition handed down by revered ancient authorities from God's Messenger - from GoD Blessed and Exalted.

The authorised spokesmen for this final conclusive Truth seek to channel religious insight for the majority of the faithful, thereby limiting creative recourse to modes of thought and critical reasoning only to expressions conforming to what has already been taught. This stifles the innate response of those individuals seeking to realise spiritual realities through the lens of their own experience, or who attempt critical reflection upon troubling issues and ambiguities in their received Tradition. One will always find some individuals in the crowd who feel the need of confirming the content of faith and doctrine through a personal seizure of understanding, and who will not be satisfied with standardised instructions about what or how to believe. They are the intelligentsia who perform the thinking and realising of truth for their fellows not inclined or endowed to do so. 
Without the work of such thinkers in the first place, today's officiating guardians of truth would never have received the doctrines they now teach people to believe in. Actually, the existence of such individuals arises from the providential intent inherent in the divine apportioning - since a pinch of yeast makes dough rise for baking bread and every cell contains a nucleus.

History and human societies today demonstrate that the official guild or guardian clique of Tradition (the 'ulam $\vec{a}$ ') frequently assumes that only one group speaks or possesses Truth while the others utter falsehood, that only one group upholds authentic doctrine while others err or deviate. This concerns not merely the question of differing or opposing doctrines, but of validating one and the same doctrine through perceptive understanding drawing insight and energy from the authentic tradition by means of fresh creative efforts of perceptive realisation. Guardians of Tradition insist upon one correct understanding (their own) of particular doctrinal issues or religious practices, and feel obligated to dismiss or smother variant views undermining their own interpretation - undermining as well their social authority, political prerogatives and personal privileges. This easily leads to an abuse of authoritarian monopoly in the guise of authoritative guidance. Such authoritarian abuse frequently operates through simplistic reduction to one privileged expression or mode of knowledge - most often: a legalist scripturebound discourse possessing a tenuous link to the depth and breadth of views enunciated by the body of authoritative interpreters of the past. This in turn has the direct effect of alienating and isolating thinking individuals not content to conform to the standardised teaching but who search for realised confirmation through personal seizure of meaning.

When we speak of 'Faith' (Arabic $\bar{\imath} m \bar{a} n$ ) it may be simply grasped in at least three ways or levels - or if you will, by three modes or functions exercised by different parts of our being. The bedrock and foundation is practice or performing deeds, the obligatory works (praxis) that religion teaches for training and purifying our physical organism and rectifying our emotional being. Based on this organic work, Faith is expressed in doctrinal formulas of belief, conviction and assent as dogmatic truths ('God, The Real, is One'). At the same time, Faith is realised and achieved as perceptive insight and understanding through personal realisation of meaning. Faith becomes real when our lived practice is informed by realised understanding validating and confirming doctrine. It is as if the external doctrine was there to call us to the practice leading to its personal realisation.

That is why the agreed doctrinal definition of $\bar{\imath} m \bar{a} n$ in Islam stresses all three components: "Faith is praxis by the limbs, and assent with the tongue, and understanding in the heart." Therefore, the operation of human intelligence and perceptive insight is a necessary factor in realising Faith. Early utterances or maxims by the first generations of Muslims confirm this: 
- There is no faith-practice for one lacking intelligence-reason (lā dīn li-man lā 'aqla la-hu);

- Intelligence-reason is the guiding-director of the man-of-faith (al- 'aql datil al-mu'min);

- God is not worshipped by anything more surpassing than human intelligencereason (mā 'ubida llāhu bi-shay' in af̣̣ala min al-'aql).

So exercising intelligence and reason is a necessary component of Faith, and without it one might be termed a muslim, but not truly a mu'min (person-offaith). In fact, like people everywhere Muslims vary among themselves in great degrees with regard to their Faith. That Muslims today speak a great deal about Islam, but far less about $\bar{m} \bar{a} n$, should be a sign for those who reflect and seek to understand. The Qur'an states forcibly in two places that many people are like uncomprehending beasts: ... deaf, dumb-nay, most of them fail to think-andunderstand (al- 'Ankabūt 29:63, \& al-Mā'idah 5:103).

Now, normative mainstream religious Tradition is concerned above all with conserving and protecting true doctrine and correct practice - two basic components of Faith. It often distrusts the well-known human capacity for selfdeception that leads to confusing error with truth - dangerous for both doctrine and practice. Over the centuries at certain times and in certain places some Muslim guardians of Tradition ('ulama') chose to demote our innate capacity to discriminate between truth and error - the human capacity to choose from among elements of received Tradition guided by illumined insight and discerning intelligence. They preferred to insist on instructing the faithful what and how to think, distrusting the power of thinking for oneself when choosing among various authoritative understandings of received Tradition. For example: this capacity for 'independent thinking' when deriving new legal rulings, they reserved only for expert jurists competent to perform the task of $i j t i h \bar{a} d$; certain jurists later denied even this power any validity in trying to "shut the door" of ijtihād, but their effort flies in the face of the divine providential purpose in endowing the human creature to function as a 'perceptive-knowing being'.

The 'ulam $\bar{a}$ ' were aided in sometimes restricting rational effort and curtailing spiritual realisation by the common human inclination to avoid the hard tasks of critical self-reflection and of purifying the perceptive faculties: training the soul and mind to serve as proper instruments for realised Faith-understanding. The great majority of us prefer to be told what to think, rather than performing the difficult work of gaining our own authentic understanding by striving with our inner being. The 'ulama' ' were further aided in these restrictive efforts by the widespread human tendency to prefer the comfort and assurance of being rightly guided and instructed in true doctrine flowing from unquestioning acceptance of 
religious authority. People feel good about themselves and safe from moral harm knowing their authorities teach only true doctrine, since conformity includes them in the group destined for eternal bliss possessing certainty. This common tendency further reinforces their feeling superior to other peoples who differ in religion, race or nationality - especially when those others may be materially or culturally more endowed (Only We shall enjoy Paradise - but They are destined for the Fire!). The Qur'an twice reprimands the Jews for thinking exactly this (alBaqarah 2:94 and 111).

But such 'unthinking imitation' or taqlìd requires marginalising the value of individual efforts seeking to confirm the reality embedded in formal doctrines by directly apprehending for oneself the reality of received Truth. The payoff for relinquishing the hard task of thinking-understanding in appropriating Truth is the self-calming comfort of possessing or owning the truth, and the reassuring certainty of belonging to the people of truth. The downside lies in the conceptual rigidity and parochial intolerance people receive in compensation, and in the shallowness of the faith they imagine they possess.

Today, thinking Muslims of conscience often find themselves estranged from the commonly experienced views and expressions voiced by many other Muslims. Rarely do they cultivate self-awareness and critical thought, seek accurate knowledge to construct a deeper understanding, and then share the fruit of their labours by nourishing food for thought to guide others. One task and burden of Muslim thinkers now is to shoulder the ambiguity and uncertainties inherent in this painful condition of estrangement, to actively embrace it and exploit its energy for fertilising one's own understanding and the understanding of one's fellows. Conforming or Confirming: which are you more comfortable with? As a perceptive knowing creature claiming the dignity of Adam endowed with the faculty of thought and understanding, do you need to be told, do you need someone to think for you - like an uncomprehending beast?

\section{Notes}

* Karim Douglas Crow is a Principal Research Fellow at IAIS Malaysia. His current projects involve research into ethical issues joining Muslim with Euro-American societies, and civilisational aspects of contemporary Islamic and Asian societies in the light of globalised trends. He is completing several books: American Evangelicals: Cultural Shifts, Militarism, and the Coming of Messiah; 'When God Created Wisdom': 'Aql Creation Narratives in Islam (forthcoming, Leiden: Brill); and his lifetime project Lamp of Knowledge: the Career and Teaching of Ja‘far al-Sādiq (d. 148 /765 CE). 